\title{
Systematic Review \\ Paediatric Antimicrobial Stewardship for Respiratory Infections in the Emergency Setting: A Systematic Review
}

\author{
Keshani Weragama, Poonam Mudgil * (D) and John Whitehall \\ Department of Paediatrics, School of Medicine, Western Sydney University, Campbelltown, NSW 2560, Australia; \\ kweragama@gmail.com (K.W.); John.Whitehall@westernsydney.edu.au (J.W.) \\ * Correspondence: p.mudgil@westernsydney.edu.au
}

Citation: Weragama, K.; Mudgil, P.; Whitehall, J. Paediatric Antimicrobial Stewardship for Respiratory Infections in the Emergency Setting: A Systematic Review. Antibiotics 2021, 10, 1366. https://doi.org/10.3390/ antibiotics 10111366

Academic Editors: Holly D. Maples and Karisma Patel

Received: 30 September 2021 Accepted: 5 November 2021 Published: 8 November 2021

Publisher's Note: MDPI stays neutral with regard to jurisdictional claims in published maps and institutional affiliations.

Copyright: (C) 2021 by the authors Licensee MDPI, Basel, Switzerland. This article is an open access article distributed under the terms and conditions of the Creative Commons Attribution (CC BY) license (https:// creativecommons.org/licenses/by/ $4.0 /)$.

\begin{abstract}
Antimicrobial resistance occurs due to the propensity of microbial pathogens to develop resistance to antibiotics over time. Antimicrobial stewardship programs (ASPs) have been developed in response to this growing crisis, to limit unnecessary antibiotic prescription through initiatives such as education-based seminars, prescribing guidelines, and rapid respiratory pathogen (RRP) testing. Paediatric patients who present to the emergency setting with respiratory symptoms are a particularly high-risk population susceptible to inappropriate antibiotic prescribing behaviours and are therefore an ideal cohort for focused ASPs. The purpose of this systematic review was to assess the efficacy and safety of ASPs in this clinical context. A systematic search of PubMed, Medline, EMBASE and the Cochrane Database of Systematic Reviews was conducted to review the current evidence. Thirteen studies were included in the review and these studies assessed a range of stewardship interventions and outcome measures. Overall, ASPs reduced the rates of antibiotic prescription, increased the prescription of narrow-spectrum antibiotics, and shortened the duration of antibiotic therapy. Multimodal interventions that were education-based and those that used RRP testing were found to be the most effective. Whilst we found strong evidence that ASPs are effective in reducing antibiotic prescribing, further studies are required to assess whether they translate to equivalent clinical outcomes.
\end{abstract}

Keywords: paediatric antibiotic stewardship; paediatric antibiotic resistance; antimicrobial stewardship programs; ASP; antimicrobial resistance; respiratory tract infections; paediatric emergency department

\section{Introduction}

Antimicrobial resistance (AMR) continues to present a growing public health challenge in an era of widespread antibiotic availability [1]. As resistance continues to rise, there is a substantial threat to the medical benefits of antibiotics and increasing mortality associated with drug-resistant infections [2]. Moreover, multidrug resistant bacteria have evolved over the past century as a result of their genetic capacities to exploit resistance genes and utilize horizontal gene transmission to develop numerous mechanisms of antibiotic resistance [3]. Strains including MRSA and VRE are of particular concern as they are responsible for significant morbidity and mortality in hospital and long-term care facilities and have recently become a major community-acquired pathogen [3,4]. Further, emerging strains such as Campylobacter species and Streptococcus pneumoniae pose a moderate to high risk, especially to vulnerable populations including preterm infants, those that are immunocompromised and the elderly [2,5,6].

The paediatric population in particular has become recognized as a nidus for the propagation of AMR in recent times [7]. Inappropriate rates of antibiotic prescription have been observed across several healthcare settings, from primary to secondary care, with a particular focus being placed on primary care [8]. Several studies have shown promise with regards to the use of ASP interventions in the primary care setting [9-11]. Further, recent reviews exploring paediatric ASPs in both inpatient and outpatient settings 
have observed the potential of these interventions in reducing antimicrobial use, healthcare costs and AMR [12]. The level of evidence surrounding the effectiveness of ASPs in the paediatric emergency department (ED) remains incoherent and requires further investigation. Following trauma, infections are the most common ED presentation in the paediatric population [13]. Due to the rare but potentially life-threatening nature of serious bacterial infections, there is a clear pattern of overprescription of antibiotics in the paediatric setting [14]. This pattern can be attributed to a number of factors including parental pressure, medical liability, diagnostic uncertainty as well as fear of adverse complications or death [14]. Antibiotics should, however, be used sparingly where there is a sufficient clinical indication or where the risk of missing a significant bacterial infection may cause significant morbidity or mortality.

Acute respiratory tract infections (ARTIs) are among the most common in children and account for a significant proportion of the antibiotics prescribed in paediatric emergency departments [15]. Studies have attributed up to $80 \%$ of antibiotic prescription in the paediatric ED setting to ARTIs [16]. With approximately $75 \%$ of ARTIs stemming from viral infections such as respiratory syncytial virus, this highlights an area of antibiotic misuse that must be addressed [17]. In some countries, vast distribution of vaccines including pneumococcal conjugate and Haemophilus influenzae Type B have had a greater effect in reducing the incidence of bacterial infections that cause severe morbidity in comparison to antibiotics [14]. Further, recent literature has found that antibiotic prescription rates for ARTIs are most commonly dependent on hospital protocol and has brought to light the overprescription of second-line antibiotics as an initial prescription [16]. These findings highlight areas of antibiotic prescription can be addressed to ensure appropriate antibiotic prescription.

Antimicrobial stewardship programs (ASPs) were introduced in healthcare settings to guide antibiotic prescribing by encouraging the use of narrow-spectrum antibiotics, optimizing dosages, and shortening the duration of antibiotics prescribed [18]. The concept of antimicrobial stewardship has been explored since 1996 and continues to evolve with the emergence of new resistance pathogens and the introduction of new antibiotics. Early ASPs focused on antibiotic de-escalation from empirical to targeted therapy [19]. More recent programs have utilized a multimodal approach, including education on antimicrobial usage, development and implementation of evidence-based guidelines to optimize antibiotic prescription [20].

It is important to assess how effective these programs are at addressing these concerns in order to make the necessary adjustments and continue to implement these strategies to help control the global burden of AMR. There are no current systematic reviews addressing the use of ASPs in the paediatric emergency department, with regards to respiratory infections. Our review will address this topic to support improvements in the delivery and quality of future paediatric ASPs.

The purpose of this systematic review was to assess the efficacy of ASPs in addressing suboptimal antibiotic prescribing for respiratory infections in the paediatric emergency setting. The primary outcome of the study was to determine whether the implementation of ASPs in paediatric emergency settings translated to judicious antibiotic prescribing in the form of narrow spectrum antibiotics, shorter courses, and reduced dosing. The secondary outcome was to determine whether the implementation of ASPs resulted in comparable clinical outcomes when compared to usual prescribing practices.

\section{Materials and Methods}

A systematic review of the literature was performed to identify primary journal articles that assessed the efficacy and safety of ASPs in guiding appropriate antibiotic prescribing. The Preferred Reporting Items for Systematic Reviews and Meta-analyses (PRISMA) guidelines were followed when performing the review. 


\subsection{Focused Question}

Are antimicrobial stewardship programs for acute respiratory presentations in the paediatric emergency setting effective in narrowing antibiotic spectrum, reducing dosage, and shortening duration of antibiotic prescription?

\subsection{PICO Question}

$\mathrm{P}$ (population): paediatric patients (aged 3 months-18 years old) presenting to the emergency department with respiratory symptoms;

I (intervention): implementation of antibiotic stewardship programs;

C (comparison): usual care;

$\mathrm{O}$ (outcome): changes in antibiotic prescribing behaviours whilst maintaining patient outcomes.

\subsection{Search Strategy}

The review was performed on 28 August 2021 and included PubMed, MEDLINE, EMBASE and the Cochrane Database of Systematic Reviews for publications from 1 August 2001 to 31 July 2021 to include studies from the last twenty years. Briefly, specific search terms included 'antimicrobial stewardship', 'antimicrobial control', 'paediatric', 'respiratory tract infection' and 'emergency department'. The complete search strategy used for MEDLINE is shown in Appendix A, which was then adapted for the remaining databases. Studies that were included were primary journal articles, had full text availability and in English language.

\subsection{Eligibility Criteria}

Inclusion criteria: all primary research articles that included children aged between 1 month-18 years who presented to an emergency department due to respiratory infections. Studies that implemented an ASP as an intervention and reported outcomes pertaining to efficacy or safety were included.

Exclusion criteria: articles were excluded if they were case series, letters, notes, conference abstracts, policy statements or opinion articles. ASPs implemented in paediatric settings other than emergency departments were excluded. For studies that included both adult and paediatric patients and the paediatric data was not available, the corresponding author was contacted, and the data requested. Studies reporting on antiviral and antifungal drugs were also excluded [21,22].

\subsection{Study Selection}

The titles and abstracts of studies that were identified by the search were screened and studies that were deemed relevant were further assessed using the full texts and reviewed in lieu of the inclusion and exclusion criteria. Additionally, reference lists of eligible studies and of relevant systematic reviews were examined to identify further studies. The search and study selection was conducted independently by two authors (KW and PM) and disagreements were resolved by consensus.

\subsection{Study Quality \& Risk of Bias}

The quality of included articles was assessed using the Integrated Quality Criteria for Systematic Review of Multiple Study Designs (ICROMS) tool [23]. Only studies that met the minimum score and mandatory criteria according to the ICROMS tool were included in the final analysis.

\subsection{Data Extraction}

Data was extracted by KW from all eligible studies using a standardized data collection form that was constructed a priori. Variables of interest included study design, location and setting, details of ASP-implemented prescribing practices and patient outcomes. 


\section{Results}

\subsection{Search Results}

In total, 228 articles were identified using the search strategy, with a filter limiting to titles published in English between 2001 and 2021. After removing 66 duplicates, the abstracts of the remaining 162 were screened and 120 were excluded for a variety of reasons including being a non-primary article, not having an ASP or QI intervention, not focusing on the paediatric population, not addressing respiratory tract presentations and for not being conducted in the emergency setting. Following the title and abstract screening, a total of 42 full-text articles were reviewed. Thirteen articles were eligible for final analysis (Figure 1).

\section{Identification of studies via databases and registers}

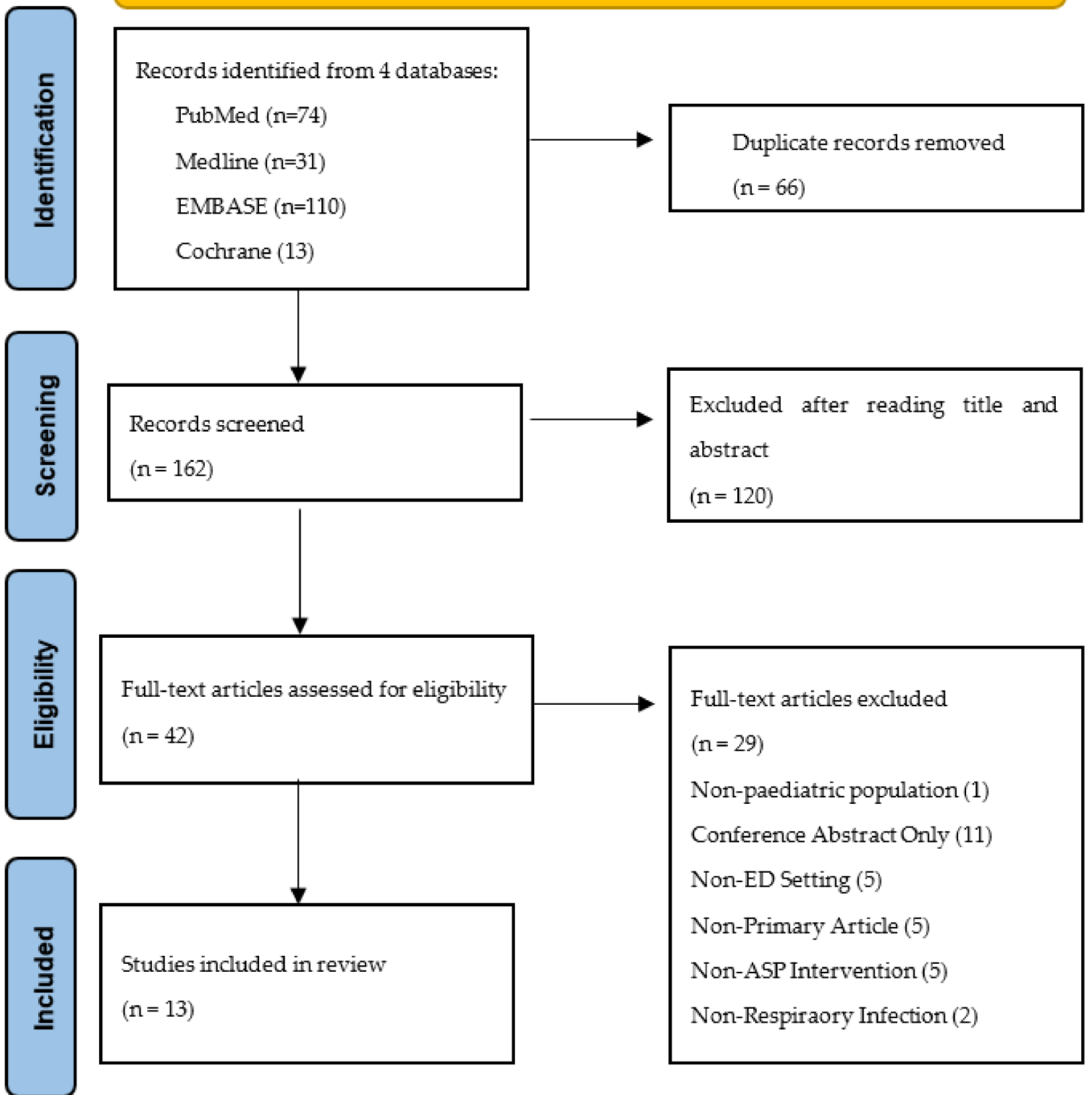

Figure 1. Preferred Reporting Items for Systematic Reviews and Meta-Analysis (PRISMA) flow diagram of study selection process. 


\subsection{Included Studies}

A summary of the included studies is provided in Table 1. These studies were published between 2013 [24] and 2021 [25,26]. Four of the thirteen studies were randomized-control studies [25,27-29], three were cohort studies [24,30,31], one was a controlled interrupted time series analysis [13] and five were noncontrolled before-and-after studies [26,32-35]. The studies were located in a variety of countries and settings, with eight of thirteen studies being conducted in the United States [24,27,29-31,33-35], and the other studies being conducted in Taiwan, France, Canada, Japan and the Netherlands [13,25,26,28,32]. All studies were conducted within the emergency departments and urgent care of hospitals, however the number and type of hospitals varied between studies. Eight of thirteen studies reported single-centre interventions $[24,26,27,30-33,35]$, whilst the other five conducted reported outcomes from multiple centres $[13,25,28,29,34]$. Further, six studies reported outcomes from paediatric hospitals only [24-26,31,35], one study used both paediatric and general hospitals [29], and the remaining five studies extracted paediatric data from a general hospital with adults and children $[13,27,28,30,32]$. The sample size was based on whether the article was reporting patient outcomes or physician outcomes but ranged from 26 [34] to 242,534 [13].

\subsection{Intervention}

The nature of ASP interventions varied greatly between included studies. Eight of these studies reported outcomes from education-based interventions which provided clinical decision tools and aids with current guidelines regarding appropriate antibiotic prescription $[13,24,28-31,33,34]$. The delivery of these interventions varied between studies but included team meetings and education seminars, distribution of physical copies of clinical decision tools, email notifications [13,24,28-31,33,34]. Further, intervention duration ranged from one month [33] to one year [13]. All eight studies used evidence-based interventions, with a majority of study interventions stemming from current clinical practice guidelines [13,24,28,30,33]. Rutman et al., developed a community-acquired pneumonia pathway during the study period based on the study population, current literature, and hospital guidelines [31]. Yadav et al., utilized interventions based on previous ASPs which were found to be effective in the outpatient setting [29]. Two of the education-based included studies also provided ongoing feedback to the physicians throughout the study as a further intervention [13,30]. Yadav et al., focused on feedback as an intervention by comparing two ASP interventions. Both interventions were based on the same campaign however the one intervention was enhanced with individualized auditing, feedback, peer comparisons and nudges [29]. Shishido et al., did not provide an education-based intervention but initiated a program that monitors the use of third generation cephalosporins (3GC) and published these prescribing patterns in monthly newsletters as a nudge-based ASP [26]. May et al., and Zhu et al., assessed the effectiveness of rapid respiratory panel (RRP) testing, to identify common viral and bacterial pathogens, as an intervention to reduce unnecessary antibiotic prescription $[27,35]$. Huang et al., conducted a retrospective study assessing the impact of a national pneumococcal conjugate vaccine (PCV13) between 2008-2012 and education-based nation-wide ASP conducted between 2013 and 2015 on antibiotic resistance to respiratory tract bacteria in children [32]. Pernica et al., observed the effectiveness of a short dose of amoxicillin in comparison to a long dose of amoxicillin to evaluate the stewardship concept of reduced length of antibiotic therapy [25]. 
Table 1. Paediatric antimicrobial stewardship for respiratory infections in the emergency setting: a systematic review (1 August 2001 to 31 July 2021$)$.

\begin{tabular}{|c|c|}
\hline $\begin{array}{l}\text { Author Year; Country; Study Period; } \\
\text { Setting }\end{array}$ & $\begin{array}{l}\text { Study Design; } \\
\text { Population and Sample Size }\end{array}$ \\
\hline $\begin{array}{l}\text { Ambroggio et al., } 2013 \text { [24]; USA; } \\
1 \text { May 2011-21 July 2012; } \\
\text { Cincinnati Children's Hospital Medical } \\
\text { Centre (CCHMC) }\end{array}$ & $\begin{array}{l}\text { Retrospective Cohort Study; } \\
3 \text { months-19 years, discharge diagnosis } \\
\text { code of pneumonia (noncomplicated or } \\
\text { pneumonia-related sx } \\
n=217\end{array}$ \\
\hline
\end{tabular}

Forrest et al., 2020 [30]; USA;

90 days;

Urgent Care Centre

\section{Cohort Study;}

Adults and children with URIs and/or head, ears, nose, throat viral illnesses

presenting to urgent care

$n=279$

\section{Objective}

Evaluate quality improvement in

setting without a formal ASP

(n)

(n)

Improve patient-centred right care for patients of 65 years and younger with URIs and/or head, ears, nose, throat viral illnesses presenting to ED from $36.2 \%$ to $80 \%$ within 90 days

\section{Huang et al., 2020 [32]; Taiwan; \\ January 2008-December 2017;}

Taichung Veterans General Hospital

\section{Retrospective noncontrolled}

before-and-after study;

Three age groups ( $<3$ years, $3-6$ years,

7-18 years)

Nasopharynx, throat swab, and sputum

culture from children $<18$ years

$n=914$

\section{Evaluate the impact of the}

implementation of the national PCY13

vaccination program and the 2013-2015

antimicrobial management project on

antimicrobial drug susceptibility or

respiratory tract bacteria in children
Intervention

Guideline Seminar

One-page summary sheet

outlining guidelin

Nurse Flag Cards

Index card with appropriate first

line Abx information for

physicians

- $\quad$ Electronic medical record (EMR)

changes to include hyperlink to

guidelines and defaulted orders to appropriate Abx orders

Rapid-cycle Quality Improvement (QI)

project with $4 \times 2$-weekly

Plan-Do-Study-Act (PDSA) cycles:

1. Team engagement: bi-weekly QI team meetings

2. Patient engagement: shared decision aid

3. Abx prescribing $5 \mathrm{DS}$ tool

4. Case Management Log

\section{Three Temporal Stages:}

1. Pre-PCV13 vaccination era$$
\text { (2008-2012) }
$$

2. Enhanced antibiotic control strategy era (2013-2015)

- Project management centre demonstration centre and

three levels of hospital

participation

3. Post antibiotic control strategy era (2016-2017)

\section{May et al, 2019 [27]; USA:}

December 2016-April 2018

$\begin{array}{ll}\text { December 2016-April 2018, } & >12 \text { months old, had symptoms of URT } \\ \text { Over } 2 \text { winter seasons and } 1 \text { intervening } & \text { or influenza-like illness and not on Abx }\end{array}$

non-respiratory season; Level $1 \mathrm{ED}$ $n=191$
Rapid, multipathogen respiratory panel

Rapid, mult
(RP) test
Evaluate whether having rapid, multipathogen test results available during the ED visit would have significant impact on management and outcomes in patients with clinical signs and symptoms of ARTI
Key Findings

Improvement in appropriate Abx prescribing in the ED following the guideline seminar $(0 \%$ to $82 \%)$

Right care increased from a baseline of $36 \%$ to $78 \%$ during the study period.

study period. rose from $33 \%$ to $93 \%$

rose from $33 \%$ to $93 \%$
Right care proper Abx prescription increased from $63 \%$ to $91 \%$

Pneumococcal vaccine decreased infective pneumococcal disease in children and improved rates of antibiotic resistance in Taiwan. Enhanced antibiotic control

strategy improved drug resistance strategy improved drug resistance
in nosocomial pathogens but had little effect on community-acquired pathogens.

Rapid RP testing associated with a trend towards decreased Abx use $(-12 \%$ difference; $p=0.06 / 0.08$, chi-square/Fisher exact test) that was larger in paediatric patients $(-19 \%$ difference; $p=0.047 / 0.07$ ) in an age-stratified post hoc analysis 
Table 1. Cont.

\begin{tabular}{|c|c|c|c|c|}
\hline $\begin{array}{l}\text { Author Year; Country; Study Period; } \\
\text { Setting }\end{array}$ & $\begin{array}{c}\text { Study Design; } \\
\text { Population and Sample Size }\end{array}$ & Objective & Intervention & Key Findings \\
\hline $\begin{array}{l}\text { McDaniel et al., } 2018 \text { [33]; USA; } \\
\text { Preintervention: January-December } \\
\text { 2015, } \\
\text { Intervention: January-Feb 2016, } \\
\text { Postintervention: March 2016-February } \\
\text { 2017; } \\
\text { Freestanding, tertiary children's hospital }\end{array}$ & $\begin{array}{l}\text { Noncontrolled before-and-after study; } \\
2 \text { months- } 18 \text { y.o at ED with primary or } \\
\text { secondary diagnosis of uncomplicated } \\
\text { CAP. } \\
n=544 \text { (preintervention) } \\
n=321 \text { (postintervention) } \\
n=290 \text { (postintervention in freestanding } \\
\text { hospital) }\end{array}$ & $\begin{array}{l}\text { Examine whether implementation of a } \\
\text { CAP pathway within } 3 \text { community } \\
\text { hospital EDs and inpatient units } \\
\text { improved process measures related to } \\
\text { appropriate laboratory testing and } \\
\text { antibiotic prescribing, and to compare } \\
\text { performance on these measures between } \\
\text { the community hospitals and a } \\
\text { freestanding children's hospital }\end{array}$ & $\begin{array}{l}\text { Clinical decision tool } \\
\text { (CDT) as a diagnostic aid for paediatric } \\
\text { patients presenting with respiratory } \\
\text { distress }\end{array}$ & $\begin{array}{l}\text { Adherence to process measures } \\
\text { increased postintervention for: } \\
\text { appropriate lab testing, } \\
\text { narrow-spectrum Abx stewardship and } \\
\text { macrolide stewardship by } 10.8 \%(95 \% \mathrm{CI} \\
=4.7 \% \text { to } 16.9 \%), 8.3 \%(95 \% \mathrm{CI}=1.5 \% \text { to } \\
15.2 \%) \text {, and } 3.1 \%(95 \% \mathrm{CI}=-4.3 \% \text { to } \\
10.4 \%) \text {, respectively }\end{array}$ \\
\hline $\begin{array}{l}\text { Ouldali et al., } 2017 \text { [13]; France; } \\
\text { November 2009-October 2014; } \\
7 \text { PEDS of Parisian university hospitals }\end{array}$ & $\begin{array}{l}\text { Multicentric noncontrolled interrupted } \\
\text { time series analysis; } \\
\text { Paediatric patients visiting ED and } \\
\text { diagnosed with ARTI. } \\
n=242,534\end{array}$ & $\begin{array}{l}\text { Assess the impact of implementing the } \\
2011 \text { national guidelines on antibiotic } \\
\text { prescriptions for ARTI in PEDs }\end{array}$ & 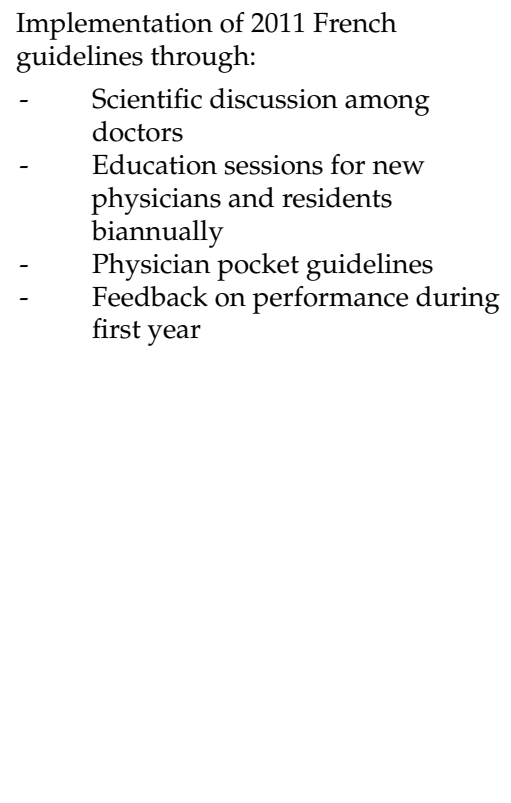 & $\begin{array}{l}\text { Antibiotic prescription rate per } \\
\text { 1000 PED visits for ARTI was } 51.0 \\
\text { preintervention (with a steady } \\
\text { increase }+0.1 \% \text { per } 15 \text {-day period) } \\
\text { Postintervention, there was a } \\
\text { significant, immediate change in } \\
\text { Abx prescription rate }(-15.5 \%, \\
p=0.01 \text { ) with a significant change } \\
\text { in slope (-0.4\% per } 15 \text {-day period, } \\
p=0.04) \\
\text { Estimated cumulative effect of } \\
\text { intervention by the end of the } \\
\text { study on Abx prescription rate for } \\
\text { ARTI per } 1000 \text { PED visits was } \\
\text {-30.9\% (95\% CI, }-42.5,-20.1 \text { ) } \\
\text { Adjusted analysis gave the same } \\
\text { results, with a cumulative effect of } \\
-28.4 \% \text { at the end of the study } \\
\text { Abx prescription rate for viral } \\
\text { ARTI for } 1000 \text { PED visits also } \\
\text { significantly decreased } \\
\text { (immediate effect: } 40.8 \% \text {; } 95 \% \text { CI, } \\
\text { - } 79.1,-2.5 ; p=0.03 \text { and no } \\
\text { change in slope) }\end{array}$ \\
\hline
\end{tabular}


Table 1. Cont.

\begin{tabular}{|c|c|c|c|c|}
\hline $\begin{array}{l}\text { Author Year; Country; Study Period; } \\
\text { Setting }\end{array}$ & $\begin{array}{c}\text { Study Design; } \\
\text { Population and Sample Size }\end{array}$ & Objective & Intervention & Key Findings \\
\hline $\begin{array}{l}\text { Pernica et al., } 2021 \text { [25]; Canada; } \\
\text { Data analysed } 1 \text { March-8 July 2020; } \\
\text { EDs of McMaster Children's Hospital } \\
\text { and the Children's Hospital of } \\
\text { Eastern Ontario }\end{array}$ & $\begin{array}{l}\text { Two-centre parallel group noninferiority } \\
\text { RCT; } \\
6 \text { months- } 10 \text { years having fever within } \\
48 \text { h, respiratory symptoms, chest } \\
\text { radiography and a primary diagnosis of } \\
\text { pneumonia. } \\
n=281\end{array}$ & $\begin{array}{l}\text { Determine whether } 5 \text { days of high-dose } \\
\text { amoxicillin for CAP was associated with } \\
\text { noninferior rates of clinical cure } \\
\text { compared with 10-days of high-dose } \\
\text { amoxicillin }\end{array}$ & $\begin{array}{l}5 \text { days of high-dose amoxicillin therapy } \\
\text { followed by } 5 \text { days of placebo } \\
\text { (intervention) vs. } 5 \text { days of high-dose } \\
\text { amoxicillin followed by a different } \\
\text { formulation of } 5 \text { days of high-dose } \\
\text { amoxicillin (control) }\end{array}$ & $\begin{array}{l}\text { Clinical cure was observed in } \\
101 / 114 \text { children }(88.6 \%) \text { in the } \\
\text { intervention group and in } 99 / 109 \\
(90.8 \%) \text { in the control group in per } \\
\text { protocol analysis (RD, }-0.016 ; \\
97.5 \% \mathrm{CI},-0.087) \\
\text { Clinical cure at } 14-21 \text { days was } \\
\text { observed in } 108 / 126(85.7 \%) \text { in the } \\
\text { intervention group and in } 106 / 126 \\
(84.1 \%) \text { in the control group in the } \\
\text { intention-to-treat analysis (RD, } \\
\text { 0.023; } 97.5 \% \mathrm{CI},-0.061)\end{array}$ \\
\hline $\begin{array}{l}\text { Rutman et al., } 2017 \text { [31]; USA; } \\
1 \text { August 2011-31 August 2013; } \\
\text { Seattle Children's Hospital, Tertiary, } \\
\text { university-affiliated 350-bed } \\
\text { freestanding }\end{array}$ & $\begin{array}{l}\text { Retrospective cohort study; } \\
2 \text { months }-18 \text { years, assigned a primary } \\
\text { ICD-9 diagnosis code associated with } \\
\text { CAP }\end{array}$ & $\begin{array}{l}\text { Determine the relationship between } \\
\text { standardising ED and inpatient care for } \\
\text { CAP and antimicrobial stewardship, } \\
\text { clinical testing, and cost }\end{array}$ & $\begin{array}{l}\text { CAP pathway implementation by the ED } \\
\text { and inpatient pathway through multiple } \\
\text { strategies: } \\
\text { - } \quad \text { Discussion at physician staff } \\
\text { meetings } \\
-\quad \text { Email notifications } \\
\text { - Mandatory web-based training } \\
\text { - Copies of pathway outside patient } \\
\text { rooms and in provider work areas }\end{array}$ & $\begin{array}{l}\text { - No statistically significant } \\
\text { differences between pre- and } \\
\text { post-intervention groups } \\
\text { Small increase in the percentage of } \\
\text { ED patients who received } \\
\text { narrow-spectrum Abx with a shift } \\
\text { from } 57 \% \text { to } 67 \% \text { after intervention } \\
\text { No significant change in ED chest } \\
\text { radiography use, ED length of } \\
\text { stay, \% of CAP admissions or cost } \\
\text { of care }\end{array}$ \\
\hline $\begin{array}{l}\text { Shishido et al., } 2021 \text { [26], Japan; } \\
\text { April 2014-September 2019; } \\
\text { Kobe Children's } \\
\text { Primary Emergency Medical Centre }\end{array}$ & $\begin{array}{l}\text { Retrospective noncontrolled } \\
\text { before-and-after study; } \\
\text { Most common diagnosis upper RTI, } \\
\text { followed by gastroenteritis and } \\
\text { bronchitis; } \\
129,156 \text { and } 28,834 \text { patients in the pre- } \\
\text { and postintervention periods }\end{array}$ & $\begin{array}{l}\text { Evaluate the effects of a nudge-based } \\
\text { ASP in reducing unnecessary } \\
\text { third-generation cephalosporin (3GC) } \\
\text { prescriptions in paediatric primary } \\
\text { emergency care centre }\end{array}$ & $\begin{array}{l}\text { The implemented ASP utilizes monthly } \\
\text { newsletters that report current } \\
\text { antimicrobial use patterns and } \\
\text { prescribing targets }\end{array}$ & 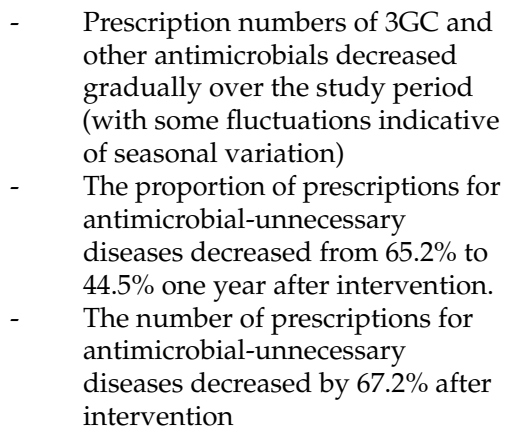 \\
\hline
\end{tabular}


Table 1. Cont.

\begin{tabular}{|c|c|c|c|c|}
\hline $\begin{array}{l}\text { Author Year; Country; Study Period; } \\
\text { Setting }\end{array}$ & $\begin{array}{l}\text { Study Design; } \\
\text { Population and Sample Size }\end{array}$ & Objective & Intervention & Key Findings \\
\hline $\begin{array}{l}\text { Van de Maat et al., } 2020 \text { [28]; The } \\
\text { Netherlands; } \\
1 \text { January 2016-27 August } 2017 \text { (baseline } \\
\text { period), 28 August 2017-12 March } 2018 \\
\text { (rollout period), intervention phase } \\
\text { every } 4 \text { weeks, data collected until } 30 \\
\text { September } 2018 \text { when target sample size } \\
\text { achieved; } \\
\text { Eight EDs in the Netherlands }\end{array}$ & $\begin{array}{l}\text { Stepped-wedge randomised trial; } \\
1-60 \text { months presenting with fever and } \\
\text { cough or dyspnoea } \\
\text { Control } n=572 \\
\text { Intervention } n=340\end{array}$ & $\begin{array}{l}\text { Safely reduce antibiotic prescription in } \\
\text { children under } 5 \text { years with suspected } \\
\text { lower RTI at the ED, by withholding } \\
\text { antibiotics in children at low or } \\
\text { intermediate risk of bacterial pneumonia, } \\
\text { as predicted by the Feverkidstool }\end{array}$ & $\begin{array}{l}\text { Antibiotics withheld in children with } \\
\text { low or intermediate predicted risk of } \\
\text { bacterial pneumonia, antibiotics } \\
\text { prescribed in children with a high } \\
\text { predicted risk (Validated clinical } \\
\text { prediction model of Feverkidstool) }\end{array}$ & $\begin{array}{l}\text { Overall Abx prescription not } \\
\text { reduced in the intervention phase } \\
\text { (30\% vs. } 25 \% \text {; [aOR] } 1.07,95 \% \text { CI } \\
0.57 \text { to } 2.01, p=0.75) \\
\text { Strategy failure decreased from } \\
23 \% \text { in the pre-intervention phase } \\
\text { to } 16 \% \text { in the intervention phase } \\
\text { (aOR 0.53, } 95 \% \text { CI } 0.32 \text { to } 0.88, \\
p=0.01) \\
\text { Per protocol analysis gave similar } \\
\text { results as intention-to-treat } \\
\text { analysis } \\
\text { Exploratory analyses intervention } \\
\text { influenced risk groups differently } \\
\text { ( } p<0.01) \text {, resulting in a reduction } \\
\text { in Abx prescriptions in } \\
\text { low /intermediate risk group }(17 \% \\
\text { to } 6 \% ; \text { aOR } 0.31 \text { [95\% CI } 0.12 \text { to } \\
0.81, p=0.02] \\
\text { Nonsignificant increase in the } \\
\text { high-risk group }(47 \% \text { to } 59 \% ; \text { aOR } \\
2.28 \text { [95\% CI } 0.84 \text { to } 6.17, p=0.09])\end{array}$ \\
\hline
\end{tabular}


Table 1. Cont.

\begin{tabular}{|c|c|c|c|c|}
\hline $\begin{array}{l}\text { Author Year; Country; Study Period; } \\
\text { Setting }\end{array}$ & $\begin{array}{l}\text { Study Design; } \\
\text { Population and Sample Size }\end{array}$ & Objective & Intervention & Key Findings \\
\hline $\begin{array}{l}\text { Weddle et al., } 2017 \text { [34]; USA; } \\
\text { Chart review at } 2 \text { preintervention time } \\
\text { points ( } 3 \mathrm{~m}, 1 \mathrm{~m} \text { before educational } \\
\text { sessions) and } 3 \text { postintervention time } \\
\text { points }(1 \mathrm{~m}, 3 \mathrm{~m}, 9 \mathrm{~m} \text { after educational } \\
\text { sessions); } \\
4 \text { UCCs affiliated with a } \\
\text { free-standing children's hospital, UCC } \\
\text { sites include both urban and suburban } \\
\text { locations }\end{array}$ & $\begin{array}{l}\text { Noncontrolled before-and-after study; } \\
\text { Patients had one of these conditions: } \\
\text { UTI, pharyngitis, SSTI, URI, AOM or } \\
\text { ABS, most common diagnosis was URI, } \\
\text { at } 74 \% \text { ( } 2576 / 3496 \text { patients) } \\
\mathrm{N}=26\end{array}$ & $\begin{array}{l}\text { To determine if educational sessions } \\
\text { would reduce inappropriate antibiotic } \\
\text { usage. }\end{array}$ & $\begin{array}{l}\text { Members of the institution's } \\
\text { antimicrobial stewardship program team } \\
\text { provided } 30 \text { min educational sessions for } \\
\text { each of the selected diagnoses }\end{array}$ & $\begin{array}{l}\text { - } 2 \% \text { reduction in inappropriate Abx } \\
\text { prescribing (10\% preintervention } \\
\text { vs. } 8 \% \text { postintervention, } p=0.02 \text { ) } \\
\text { Inappropriate antibiotic use } \\
\text { decreased in those who attended } \\
\text { the educational session (9\% } \\
\text { preintervention vs. } 6 \% \\
\text { postintervention, } p<0.01) \\
\text { No significant change in } \\
\text { inappropriate Abx prescribing in } \\
\text { providers not attending } \\
\text { educational sessions (10\% } \\
\text { preintervention vs. } 9 \% \\
\text { postintervention) } \\
\text { All diagnosis groups showed a } \\
\text { decrease in inappropriate Abx } \\
\text { prescribing except for SSTI and } \\
\text { AOM } \\
\text { Wrong dosage observed in } 22 \% \\
\text { (12/55) of patients with confirmed } \\
\text { group A beta-haemolytic } \\
\text { streptococcal pharyngitis } \\
\text { Patients' demography impacted } \\
\text { antibiotic prescribing } \\
\text { Self-pay patients were more likely } \\
\text { to receive an inappropriate Abx } \\
\text { for pharyngitis but were less likely } \\
\text { to receive an Abx for diagnosis of } \\
\text { SSTI } \\
\text { Old age correlated with likelihood } \\
\text { of received Abx for viral URI } \\
\text { diagnosis } \\
\text { Children older than } 3 \text { y were more } \\
\text { likely to receive an inappropriate } \\
\text { Abx } \\
\text { Children } 1-3 \text { y or older than } 6 \text { y } \\
\text { were less likely to receive initial } \\
\text { Abx than children outside these } \\
\text { age ranges }\end{array}$ \\
\hline
\end{tabular}


Table 1. Cont.

\begin{tabular}{|c|c|c|c|c|}
\hline $\begin{array}{l}\text { Author Year; Country; Study Period; } \\
\text { Setting }\end{array}$ & $\begin{array}{l}\text { Study Design; } \\
\text { Population and Sample Size }\end{array}$ & Objective & Intervention & Key Findings \\
\hline $\begin{array}{l}\text { Yadav et al., } 2019 \text { [29]; USA; } \\
\text { July 2017-February } 2018 \text { at UC Davis } \\
\text { and Harbor-UCLA, November } \\
\text { 2017-February } 2018 \text { at CHCO, a } \\
\text { 12-month baseline period for statistical } \\
\text { analysis; } \\
\text { five EDs and four UCCs }\end{array}$ & $\begin{array}{l}\text { Pragmatic, cluster RCT, } \\
\text { Licensed clinicians at the participating } \\
\text { sites eligible, } \\
\text { diagnoses (primary and secondary) from } \\
\text { the ICD-10-CM codes consistent with } \\
\text { antibiotic-nonresponsive ARI diagnoses }\end{array}$ & $\begin{array}{l}\text { Compare the effectiveness of an } \\
\text { antibiotic stewardship intervention } \\
\text { adapted for acute ambulatory care } \\
\text { settings to a stewardship intervention } \\
\text { that additionally incorporates } \\
\text { behavioural nudges in reducing } \\
\text { inappropriate prescriptions. }\end{array}$ & $\begin{array}{l}\text { Two interventions are compared: } \\
\text { 1. Adapted intervention that } \\
\text { consisted of education for patients } \\
\text { and providers using materials } \\
\text { from CDC's Get Smart (currently } \\
\text { called Be Antibiotics Aware) } \\
\text { campaign adapted for the acute } \\
\text { care setting, led by a physician } \\
\text { champion at each site. } \\
\text { 2. Enhanced intervention that } \\
\text { incorporated the adapted Get } \\
\text { Smart campaign, in addition to } \\
\text { individualized audit and feedback, } \\
\text { peer comparisons, and nudges. }\end{array}$ & $\begin{array}{l}\text { Antibiotic prescribing for ARI } \\
\text { visits dropped from } 6.2 \%(95 \% \\
\text { confidence interval [CI] }=4.5 \% \text { to } \\
7.9 \%) \text { to } 2.4 \%(95 \% \mathrm{CI}=1.3 \% \text { to } \\
3.4 \%) \\
\text { A significant reduction in } \\
\text { inappropriate prescribing after } \\
\text { adjusting for health-system and } \\
\text { provider-level effects from } 2.2 \% \\
\text { ( } 95 \% \mathrm{CI}=1.0 \% \text { to } 3.4 \%) \text { to } 1.5 \% \\
(95 \% \mathrm{CI}=0.7 \% \text { to } 2.3 \%) \text { with an } \\
\text { odds ratio of } 0.67(95 \% \mathrm{CI}=0.54 \text { to } \\
0.82) \text {. } \\
\text { Difference-in-differences between } \\
\text { the two interventions was not } \\
\text { significantly different. }\end{array}$ \\
\hline $\begin{array}{l}\text { Zhu et al., } 2019 \text { [35]; USA; } \\
\text { 16 December 2013-15 December, 2015; } \\
\text { ProMedica Toledo Children's Hospital }\end{array}$ & $\begin{array}{l}\text { Retrospective } \\
\text { Noncontrolled before-and-after study; } \\
1 \text { month-18 years with uncomplicated } \\
\text { ARTI admitted into the hospital or ED } \\
\text { (those in the ED, had to be discharged } \\
\text { from the ED for inclusion) } \\
\text { ED group: } n=939\end{array}$ & $\begin{array}{l}\text { Assess whether respiratory pathogen } \\
\text { panel (RPP) testing decreases antibiotic } \\
\text { days of therapy and length of hospital } \\
\text { stay for paediatric patients with ARTI }\end{array}$ & $\begin{array}{l}\text { Samples for RPP testing were collected } \\
\text { via nasopharyngeal swabs. RPP was } \\
\text { performed through PCR detection by } \\
\text { BioFire FilmArray Assay which } \\
\text { identifies common viral pathogens, as } \\
\text { well as common bacterial pathogens }\end{array}$ & 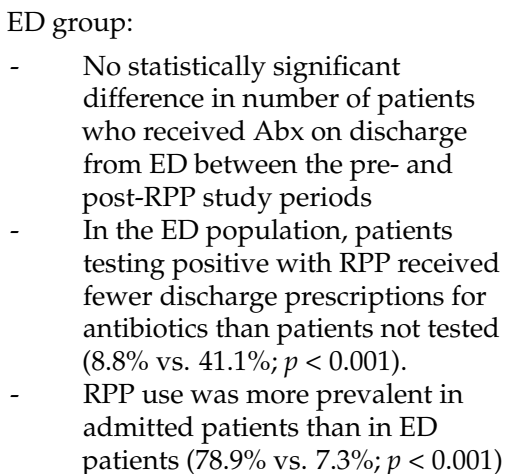 \\
\hline
\end{tabular}




\subsection{Primary Outcome}

The primary outcomes reported in the included studies are heterogeneous, ranging from antibiotic prescription rate [24] to susceptibility of respiratory pathogens to antimicrobial agents [32] (Table 2). Many studies reported the proportion of appropriate antibiotic prescriptions as a primary outcome, comparing rates both pre- and postintervention $[13,24,27-30,34]$. Two studies looked at the prescription rate of specific antibiotics, namely ampicillin, third generation cephalosporins [26,31]. McDaniel et al., explored whether physicians adhered to the diagnostic measures outlined in the clinical decision tool and then assessed therapeutic measures including changes in the prescription of macrolides and narrow spectrum antibiotics [33]. Zhu et al., focused on the number of days of antibiotic therapy and the number of patients who left ED with antibiotics [35]. Several studies evaluated clinical as a primary measure. Van de Maat et al.,, in addition to antibiotic prescription rate, also assessed strategy failure within a week of the initial ED visit [28]. Similarly, Forrest et al.,, in addition to appropriate use of antibiotics, also assessed physician and patient engagement and satisfaction with the intervention as a primary outcome [30]. Pernica et al., also explored clinical cure 14-21 days after presentation as a primary outcome [25]. Finally, Huang et al., retrospectively assessed the susceptibility of respiratory pathogens to antimicrobial agents over three major time periods [32].

Table 2. Outcome measures of interest reported in included studies.

\begin{tabular}{|c|c|c|c|c|c|c|}
\hline & & \multicolumn{5}{|c|}{ Outcomes } \\
\hline Authors & Intervention & $\begin{array}{c}\text { Reduction in } \\
\text { Inappropriate } \\
\text { Antibiotic } \\
\text { Prescription }\end{array}$ & $\begin{array}{c}\text { Reduction in } \\
\text { prescription of } \\
\text { Broad-Spectrum } \\
\text { Antibiotics }\end{array}$ & $\begin{array}{c}\text { Reduction in } \\
\text { Duration of } \\
\text { Antibiotic Therapy }\end{array}$ & $\begin{array}{l}\text { Patient Clinical } \\
\text { Outcomes }\end{array}$ & Reduction of AMR \\
\hline Ambroggio et al. & $\begin{array}{l}\text { Multifaceted } \\
\text { education-based } \\
\text { intervention }\end{array}$ & ND & $\begin{array}{c}\text { Appropriate } \\
\text { first-line } \mathrm{Abx} \\
\text { prescription: } 0 \% \text { to } \\
82 \%\end{array}$ & ND & ND & ND \\
\hline Forrest et al. [30] & $\begin{array}{l}\text { Multifaceted } \\
\text { education-based } \\
\text { intervention }\end{array}$ & $\begin{array}{l}\text { Appropriate Abx } \\
\text { prescription } \\
\text { increased from } 63 \% \\
\text { to } 91 \%\end{array}$ & ND & ND & $\begin{array}{c}\text { Increased from } \\
36 \% \text { to } 78 \%\end{array}$ & ND \\
\hline Huang et al. [32] & $\begin{array}{l}\text { Multifaceted } \\
\text { education-based } \\
\text { intervention }\end{array}$ & ND & ND & ND & ND & $p<0.05$ \\
\hline May et al. [27] & $\begin{array}{c}\text { Rapid, } \\
\text { multipathogen } \\
\text { respiratory panel } \\
\text { test }\end{array}$ & $\begin{array}{c}-12 \% ; \\
95 \% \text { CI }[-25 \% \text { to } \\
0.4 \%] ; p=0.06 / 0.08\end{array}$ & ND & ND & ND & ND \\
\hline McDaniel et al. [33] & $\begin{array}{c}\text { Multifaceted } \\
\text { education-based } \\
\text { intervention }\end{array}$ & ND & $\begin{array}{c}-10.8 \% \\
95 \% \text { CI }[-4.7 \% \text { to } \\
-16.9 \%] \\
p<0.001\end{array}$ & ND & ND & ND \\
\hline Ouldali et al. [13] & $\begin{array}{l}\text { Multifaceted } \\
\text { education-based } \\
\text { intervention }\end{array}$ & $\begin{array}{c}-0.4 \% \text { per } 15 \text {-day } \\
\text { period; } \\
p=0.04\end{array}$ & ND & ND & ND & ND \\
\hline Pernica et al. [25] & $\begin{array}{l}\text { Reduced antibiotic } \\
\text { therapy duration }\end{array}$ & ND & ND & ND & $\begin{array}{c}\text { RD, }-0.016 ; \\
97.5 \% \text { CI }-0.087\end{array}$ & ND \\
\hline Rutman et al. [31] & $\begin{array}{l}\text { Multifaceted } \\
\text { education-based } \\
\text { intervention }\end{array}$ & ND & $-10 \%$ & ND & ND & ND \\
\hline Shishido et al. [26] & $\begin{array}{c}\text { Feedback, } \\
\text { peer-comparison } \\
\text { and nudge-based } \\
\text { intervention }\end{array}$ & $\begin{array}{c}-67.2 \% \\
\text { Regression } \\
\text { coefficient }-0.58 ; p \\
<0.001\end{array}$ & ND & ND & ND & ND \\
\hline $\begin{array}{l}\text { Van de Maat et al. } \\
\text { [28] }\end{array}$ & $\begin{array}{l}\text { Multifaceted } \\
\text { education-based } \\
\text { intervention }\end{array}$ & $\begin{array}{c}\text { [aOR] 1.07; } \\
95 \% \text { CI } 0.57 \text { to } 2.01 ; \\
p=0.75\end{array}$ & ND & ND & $\begin{array}{c}\text { [aOR] } 0.53 ; \\
95 \% \text { CI } 0.32 \text { to } \\
0.88 ; \\
p=0.01\end{array}$ & ND \\
\hline Weddle et al. [34] & $\begin{array}{l}\text { Multifaceted } \\
\text { education-based } \\
\text { intervention }\end{array}$ & $\begin{array}{c}-2 \% \\
p=0.02\end{array}$ & ND & ND & ND & ND \\
\hline Yadav et al. [29] & $\begin{array}{c}\text { Feedback, } \\
\text { peer-comparison } \\
\text { and nudge-based } \\
\text { intervention }\end{array}$ & $\begin{array}{c}\mathrm{OR}=0.67 \\
95 \% \mathrm{CI}=0.54 \text { to } \\
0.82\end{array}$ & ND & ND & ND & ND \\
\hline Zhu et al. [36] & $\begin{array}{l}\text { Rapid respiratory } \\
\text { pathogen testing }\end{array}$ & $\begin{array}{c}78.9 \% \text { vs. } 7.3 \% ; \\
p<0.001\end{array}$ & ND & ND & ND & ND \\
\hline
\end{tabular}

Green-reduction with statistical significance; Yellow-reduction withoyt statistical significance; ND—not done. 


\subsection{Efficacy of ASPS}

\subsubsection{Education-Based Interventions}

Of the studies based on education-based interventions with clinical decision tools, a significant reduction of overall antibiotic use and inappropriate antibiotic prescription was reported by six studies $[13,24,29,30,33,34]$. Two studies found an increase in appropriate antibiotic prescription, however, did not reach statistical significance [28,31]. Two studies reported an increase in the use of narrow-spectrum antibiotics; McDaniel et al., observed a statistically significant increase of $8.3 \%(95 \%$ CI $21.5,15.2)$ and Rutman et al., observed a slight increase from 57 to $67 \%$ postintervention in the ED population [31,33].

\subsubsection{Feedback for STUDY Participants}

Study interventions which provided ongoing feedback to participants throughout the study period showed a significant increase in appropriate antibiotic use. Ouldali et al., provided feedback during the first year of intervention and observed a $-15.5 \%, p=0.01$ decrease in antibiotic prescription rate and with an estimated cumulative effect of intervention of $-30.9 \%(95 \% \mathrm{CI}-42.5,-20.1)$ [13]. It is however difficult to attribute this change to feedback only as Yadav et al., found no significant difference-in-differences between the arm of his study that received feedback in comparison to the group that did not receive feedback [29].

\subsubsection{RRP Testing}

Of the two studies based on RRP testing interventions, both reported a decrease in antibiotic use $[27,35]$. However, only one paper reported a statistically significant reduction [27]. Although, Zhu et al., did not find a significant difference in the number of patients who received antibiotics, there was a statistically significant reduction $(-32.3 \%$, $p<0.001)$ in discharge antibiotic prescriptions between the number of patients testing positive with RRP in comparison to patients who were not tested [35].

\subsubsection{Impact of Vaccinations/Enhanced Antimicrobial Control}

Huang et al., reported a significant reduction in the resistance of antibiotics in response to the pneumococcal vaccination program across Taiwan. Certain pathogens such as $H$. influenzae however, decreased in susceptibility throughout the study period. Further, the enhanced antibiotic strategy, including an education-based ASP towards the end of the study only showed a significant improvement of drug resistance in nosocomial pathogens and not community-associated pathogens [32].

\subsection{Clinical Outcomes following ASP Search Results}

Pernica et al., observed the effects of a short-course high-dose antibiotic (intervention) in comparison to a long course of high-dose antibiotics (control) on clinical cure between 14-21 days [25]. Clinical cure was clearly defined and included an initial improvement during the first 4 days, improvement in dyspnoea and work or breathing, only one or no fever spikes and a lack of further antibiotic prescription. Clinical cure at 14-21 days postintervention was observed in $85.7 \%$ in the intervention group and $84.1 \%$ in the control group (RD $0.023 ; 97.5 \% \mathrm{CI}-0.061$ ). Therefore, this study found that a short-course of antibiotics was comparable to a long-course in the treatment of community-acquired pneumonia presentations in the ED [25]. Van de Maat et al., also included strategy failure as a primary outcome following the utilization of a clinical decision tool. Strategy failure included a secondary antibiotic prescription, hospitalization, recurrent fever, oxygen dependency or further complications within 7 days. In this study, a significant decrease in strategy failure from $23 \%$ to $16 \%$ (aOR $0.53,95 \%$ CI $0.32,0.88, p=0.01$ ) was observed following intervention [28]. 


\subsection{Risk of Bias}

All included studies were assessed for bias using the ICROMS tool. All studies met the mandatory criteria and minimum score required to be deemed of fair quality and therefore were included for review (Appendices B-D)

\section{Discussion}

The global burden of AMR, particularly in the context of increased antibiotic use is rapidly increasing. ASPs were developed in response to this growing public health issue and are aimed at optimising antibiotic prescription, whilst maintaining patient care [36]. The emergency setting is imperative for efforts in antimicrobial stewardship due to the high frequency of infectious presentations and acute outpatient referrals [36]. Recent literature exploring the use of ASPs in the emergency setting have shown promise in promoting appropriate prescription of antibiotics [37-39]. Savoldi et al., associated a reduction in antibiotic costs and usage with the implementation of a general ED-based ASP [38]. Further, patient outcomes were also improved with an overall reduction in patient length of stay and reduced rates of Clostridioides difficile infection in patients admitted from ED [38]. May et al., assessed the effectiveness of a multifaceted ASP for ED patients with skin and soft tissue infections (SSTI) [39]. This study found only a modest improvement in appropriate antibiotic use, with a decrease in the duration of antibiotic therapies [39].

There is limited evidence surrounding the use of ASPs in the ED setting for the paediatric population, in particular with regard to ARTIs.

This systematic review looking at the effectiveness of ASPs for respiratory presentations in the paediatric emergency setting shows that multiple methods of delivering education-based ASPs translate to improved antibiotic prescribing and equivalent or improved clinical outcomes and safety, which are sustainable. Further, the availability of diagnostic tools such as RRP testing facilities shows promise in increasing the rate of appropriate antibiotic prescribing.

When evaluating the efficacy of ASPs, the most commonly used measures included proportion of appropriate first-line antibiotic use and broad-spectrum antibiotics. The effects of overall antibiotic use were well reported by the included studies, and the postintervention difference was statistically significant in nine of thirteen studies $[13,24,26,27,29,30,33-35]$. As effects were seen in a variety of ASP multimodal intervention types, it can be difficult to ascertain which strategies optimised ASP delivery and therefore efficacy. A number of included studies implemented a comparable approach when delivering ASPs, with an education-based seminar followed by updates to physical handbooks and electronic medical record systems $[13,24,28-31,33,34]$. One of these studies by Ambroggio et al., implemented a 'level of reliability' (LOR) measure which indicates the likelihood of an intervention to fail in the system over time [24]. Based on their results, the study allocated their ASP delivery methods including guideline seminars, recommendations in medical staff updates, nurse flag cards, index cards with appropriate antibiotic information and resident reports as a level one LOR, indicating the intervention would only fail once or twice for every ten encounters [24]. This is in line with current literature which supports the use of multimodal, education-based ASPs, attributing these programs to changes in knowledge, attitude, and quality of antibiotic prescription [40-42]. On the other hand, a retrospective study by Huang et al., found that the pneumococcal vaccine significantly improved AMR in Taiwan, however, although the education-based ASP improved drug resistance of nosocomial pathogens, it did not have a significant effect on communityassociated pathogens [32].

Further, two other included studies although implementing education-based clinical tools, reported a decrease in antibiotic use, however, these results did not reach statistical significance [28,31]. Rutman et al., attributed this to contextual factors including leadership support and hospital culture, whereas Van de Maat et al., recognised this lack of significance was likely due to a low number of baseline prescription rates in comparison to other studies and a large proportion of high-risk patients present during the study period [28,31]. 
Therefore, further research with sufficient power and adequate control of confounding factors should be conducted to confirm these findings.

There is conflicting evidence regarding the use of feedback techniques when delivering an ASP, with some studies reporting a significant change in the prescription of targeted antibiotics [43], and others not seeing an improvement [44]. Two included studies provided physician feedback as part of their ASP intervention, and both found a statistically significant reduction in rates of antibiotic prescription [13,29]. In the RCT conducted by Yadav et al., feedback was only provided for the intervention arm of the study, and a statistically significant reduction in inappropriate prescribing from $2.2 \%$ (95\% CI 1.0-3.4) to $1.5 \%$ (95\% CI 0.7-2.3) [OR 0.67] was reported. This study, however, included both adult and paediatric populations in this analysis, therefore future RCTs need to be conducted to confirm this results in the paediatric population alone [29].

In the adult population, a significant reduction in inappropriate antibiotic prescription $(41.6 \%$ versus $11 \%, p<0.0001)$ after the utilisation of RRP has been reported [45]. This is in line with recent literature highlighting the potential of rapid respiratory testing to increase the appropriate prescribing of antimicrobial agents [46]. This evidence, however, is limited for the paediatric population. May et al., conducted an RCT assessing the effectiveness of RRP testing in comparison to the usual care on antimicrobial stewardship [27]. The study was ceased before it was able to reach the required sample size, however displayed an overall reduction of antibiotic use with RRP testing $(-12 \%$ difference; $p=0.06)$ that was larger in the paediatric patients $(-19 \%$ difference; $p=0.047)$ in age-stratified post hoc analysis [27]. Further, Zhu et al., also reported a statistically significant decrease in antibiotic prescriptions for discharged paediatric patients who underwent RRP testing in comparison to those not tested $(8.8 \%$ versus $41.1 \%, p<0.001)$ [35]. However, the utilisation of RRP testing was significantly less in the ED setting in comparison to inpatient wards ( $7.3 \%$ versus $78.9 \%, p<0.001)$ [35]. Zhu et al., attributes this difference to the cost of RRP, however further research is required to assess the deterrents for effective ED use [35].

Although there is evidence for the use of RRP testing, there is limited evidence on the use of other diagnostic testing methods, such as chest radiographs and blood tests, as a method for antimicrobial stewardship. McDaniel et al., assessed adherence to diagnostic measures within an intervention including complete blood count, blood cultures, acutephase reactants, and chest radiographs as an intervention to improve rates of appropriate antibiotic prescription and associated an increase in adherence $(+10.8 \%, 95 \%$ CI $4.7 \%$, $16.9 \%)$ with an increase in narrow-spectrum antibiotic prescription $(8.3 \%, 95 \%$ CI $1.5 \%$, $15.2 \%)$. Although there is a significant increase in both measures, there was no clear analysis conducted to ensure a correlation. Therefore, an RCT directly assessing the effect of diagnostic testing methods on antibiotic stewardship would be beneficial.

The success of an ASP cannot be completely appreciated without the clinical outcomes of the patients included in the study population. The majority of current literature focuses on the stewardship measures such antibiotic use and cost, however, more recently the literature is encouraging a shift in focus towards the clinical impact of ASPs [47]. Only two of our included studies reported patient clinical outcomes as a primary measure of their studies $[25,28]$. Van de Maat et al., reported 'strategy failure' as a primary outcome, defined as the need for further antibiotic prescription, rehospitalisation, persisting fevers or oxygen dependency within seven days or any other notable complications [28]. Similarly, Pernica et al., reported 'clinical cure' as their only outcome measure as they compared the success of a short course of antibiotics for community-acquired pneumonia in comparison to a long dose [25]. One included study reported patient outcomes as a secondary outcome referred to as 'right care', however did not report on specific patient outcomes following discharge from ED [30]. Further, four included studies addressed patient outcomes in their discussion, reporting that there were no significant differences in patient outcomes between the pre- and postintervention groups $[13,27,31,33]$. Five included studies did not to address patient outcomes throughout the study $[24,26,29,34,35]$. This highlights a gap in the current literature which needs to be addressed to ensure ASPs are being implemented safely as 
well as efficaciously. Therefore, future research on ASPs should always include clinical outcomes as a primary measure of success. Further, the distribution of ARTI emergency presentations across the paediatric population differs between paediatric age groups, with children aged $<1$ to 4 years old being the most frequent in comparison to children aged 5-18 years old [48]. Future research on paediatric ASPs should strive to define the most appropriate ASP design for different age groups within the paediatric population to ensure the applicability and effectiveness of intervention.

\section{Strengths and Limitations}

This study has many advantages. The inclusion of only studies meeting the mandatory criteria and minimum score requirements from the ICROMS risk of bias tool, ensured only good-quality papers were reviewed. Further, a variety of ASP interventions were reviewed, providing an overview and opportunity for comparison. This provides a strong basis for future ASP development and implementation.

Our study has some limitations. Firstly, only four databases were searched, and some references may have been missed. Further, the search was restricted to papers published in English, which may have led to some relevant papers being overlooked. It should also be noted that with the high volume of observational studies included in this review, a risk of reporting bias is present however, this was minimised by the inclusion of only high-quality studies. Lastly, the phrase 'antibiotic stewardship', as a relatively new term, may not have applied to all studies exploring this concept which may have resulted in relevant papers being missed.

\section{Conclusions and Recommendations}

We conclude that most ASPs are effective in addressing suboptimal antibiotic prescription for respiratory infection in the paediatric emergency setting. Successful delivery of both education-based ASPs, as well as clinical tools such as RRP testing, translated to judicious antibiotic prescribing with a reduction in overall antibiotic prescribing and increased the proportion of narrow-spectrum antibiotics and short-course antibiotic therapies. As many included papers were not RCTs, there are many factors in the delivery of ASPs that further research can shed some light on. We recommend further research into the effectiveness of ASPs for respiratory infections in the paediatric ED setting. Such studies should aim to identify focused strategies to improve the adherence to and efficacy of ASPs and strive to include clinical outcomes as a primary measure of success.

Author Contributions: Conceptualization, P.M.; methodology, K.W., P.M.; validation, K.W., P.M.; formal analysis, K.W.; investigation, K.W.; data curation, K.W.; writing-original draft preparation, K.W.; writing-review and editing, K.W., P.M., J.W.; resources, P.M.; supervision, P.M.; project administration, P.M. All authors have read and agreed to the published version of the manuscript.

Funding: This research received no external funding.

Institutional Review Board Statement: Not applicable.

Informed Consent Statement: Not applicable.

Data Availability Statement: All data is contained within this article.

Conflicts of Interest: The authors declare no conflict of interest. 


\section{Appendix A}

Table A1. Search Strategy Used for PubMed, MEDLINE, Embase and Cochrane Database of Systematic Reviews.

\begin{tabular}{cc}
\hline Step & Search Terms \\
\hline 1 & 'antimicrobial stewardship' \\
2 & 'antimicrobial control' \\
3 & 'antibiotic control' \\
4 & 'antibiotic stewardship' \\
5 & 'child *' \\
6 & 'paediatric' \\
7 & 'pediatric' \\
8 & 'infant' \\
9 & 'neonat' \\
10 & 'respiratory tract infection' \\
11 & 'chest infection' \\
12 & 'lung infection' \\
13 & 'pneumo ${ }^{* \prime}$ \\
14 & 'emergency' \\
15 & 'emergency department' \\
16 & 'acute care' \\
17 & 'critical care' \\
18 & 'urgent care' \\
19 & 1 OR 2 OR 3 OR 4 \\
20 & 5 OR 6 OR 7 OR 8 OR 9 \\
21 & 10 OR 11 OR 12 OR 13 \\
22 & 14 OR 15 OR 16 OR 17 OR 18 \\
23 & 19 AND 20 AND 21 AND 22 \\
\hline
\end{tabular}

${ }^{*}$ wildcard in search term.

\section{Appendix B}

Table A2. ICROMS Quality Criteria for Application per Study Design.

\begin{tabular}{|c|c|c|c|c|c|c|c|c|c|}
\hline & \multicolumn{2}{|r|}{ Quality Criteria } & \multicolumn{7}{|c|}{ Study Design ** } \\
\hline & Dimension & Specific Criteria * & RCT & CBA & CITS & NCITS & NCBA & CS & QUAL \\
\hline \multirow[t]{5}{*}{1} & $\begin{array}{l}\text { Clear aims and } \\
\text { justification }\end{array}$ & $\begin{array}{l}\text { a. Clear statement of the aims of the } \\
\text { research? }\end{array}$ & YY & YY & YY & YY & YY & YY & YY \\
\hline & & $\begin{array}{l}\text { b. Rationale for number of pre- and } \\
\text { postintervention points or adequate baseline } \\
\text { measurement }\end{array}$ & $\mathrm{N}$ & $\mathrm{N}$ & Y & YY & YY & $\mathrm{N}$ & $\mathrm{N}$ \\
\hline & & c. Explanation for lack of control group & $\mathrm{N}$ & $\mathrm{N}$ & $\mathrm{N}$ & $\mathrm{Y}$ & $\mathrm{Y}$ & $\mathrm{N}$ & $\mathrm{N}$ \\
\hline & & $\begin{array}{l}\text { d. Appropriateness of qualitative } \\
\text { methodology }\end{array}$ & $\mathrm{N}$ & $\mathrm{N}$ & $\mathrm{N}$ & $\mathrm{N}$ & $\mathrm{N}$ & $\mathrm{N}$ & Y \\
\hline & & e. Appropriate study design & $\mathrm{N}$ & $\mathrm{N}$ & $\mathrm{N}$ & $\mathrm{N}$ & $\mathrm{N}$ & $\mathrm{N}$ & YY \\
\hline \multirow[t]{6}{*}{2} & $\begin{array}{l}\text { Managing bias in } \\
\text { sampling or between } \\
\text { groups }\end{array}$ & a. Sequence generation & YY & $\mathrm{N}$ & $\mathrm{N}$ & $\mathrm{N}$ & $\mathrm{N}$ & $\mathrm{N}$ & $\mathrm{N}$ \\
\hline & & b. Allocation concealment & YY & $\mathrm{N}$ & $\mathrm{N}$ & $\mathrm{N}$ & $\mathrm{N}$ & $\mathrm{N}$ & $\mathrm{N}$ \\
\hline & & c. Justification for sample choice & $\mathrm{N}$ & $\mathrm{N}$ & $\mathrm{N}$ & YY & YY & $\mathrm{N}$ & $\mathrm{N}$ \\
\hline & & $\begin{array}{l}\text { d. Intervention and control group selection } \\
\text { designed to protect against systematic } \\
\text { difference/selection bias }\end{array}$ & $\mathrm{N}$ & YY & $\mathrm{N}$ & $\mathrm{N}$ & $\mathrm{N}$ & $\mathrm{N}$ & $\mathrm{N}$ \\
\hline & & e. Comparability of groups & $\mathrm{N}$ & $\mathrm{N}$ & $\mathrm{N}$ & $\mathrm{N}$ & $\mathrm{N}$ & YY & $\mathrm{N}$ \\
\hline & & f. Sampling and recruitment & $\mathrm{N}$ & $\mathrm{N}$ & $\mathrm{N}$ & $\mathrm{N}$ & $\mathrm{N}$ & $\mathrm{N}$ & $Y Y$ \\
\hline \multirow[t]{2}{*}{3} & $\begin{array}{l}\text { Managing bias in } \\
\text { outcome measurements }\end{array}$ & a. Blinding & YY & $\mathrm{N}$ & $\mathrm{N}$ & $\mathrm{N}$ & $\mathrm{N}$ & $\mathrm{N}$ & $\mathrm{N}$ \\
\hline & & $\begin{array}{l}\text { b. Baseline measurement and protection } \\
\text { against selection bias }\end{array}$ & $\mathrm{N}$ & YY & $\mathrm{N}$ & $\mathrm{N}$ & $\mathrm{N}$ & $\mathrm{N}$ & $\mathrm{N}$ \\
\hline
\end{tabular}


Table A2. Cont.

\begin{tabular}{|c|c|c|c|c|c|c|c|c|c|}
\hline & \multicolumn{2}{|r|}{ Quality Criteria } & \multicolumn{7}{|c|}{ Study Design ** } \\
\hline \multirow[b]{6}{*}{4} & \multirow[b]{6}{*}{$\begin{array}{l}\text { Managing bias in } \\
\text { follow-up }\end{array}$} & \multirow{6}{*}{$\begin{array}{l}\text { c. Protection against contamination } \\
\text { d. Protection against secular changes } \\
\text { e. Protection against detection bias: Blinded } \\
\text { assessment of primary outcome measures } \\
\text { f. Reliable primary outcome measures } \\
\text { g. Comparability of outcomes } \\
\text { a. Follow-up of subjects (protection against } \\
\text { exclusion bias) }\end{array}$} & $\mathrm{N}$ & YY & $\mathrm{N}$ & $\mathrm{N}$ & $\mathrm{N}$ & $\mathrm{N}$ & $\mathrm{N}$ \\
\hline & & & $\mathrm{N}$ & $\mathrm{N}$ & YY & $\mathrm{N}$ & $\mathrm{N}$ & $\mathrm{N}$ & $\mathrm{N}$ \\
\hline & & & $\mathrm{Y}$ & $\mathrm{Y}$ & $\mathrm{Y}$ & $\mathrm{Y}$ & $\mathrm{Y}$ & $\mathrm{Y}$ & $\mathrm{N}$ \\
\hline & & & $\mathrm{Y}$ & $\mathrm{Y}$ & $\mathrm{Y}$ & $\mathrm{Y}$ & $\mathrm{Y}$ & $\mathrm{Y}$ & $\mathrm{Y}$ \\
\hline & & & $\mathrm{N}$ & $\mathrm{N}$ & $\mathrm{N}$ & $\mathrm{N}$ & $\mathrm{N}$ & YY & $\mathrm{N}$ \\
\hline & & & $\mathrm{Y}$ & $\mathrm{N}$ & $\mathrm{N}$ & $\mathrm{N}$ & $\mathrm{N}$ & $\mathrm{N}$ & $\mathrm{N}$ \\
\hline \multirow{5}{*}{5} & \multirow{5}{*}{$\begin{array}{l}\text { Managing bias in other } \\
\text { study aspects }\end{array}$} & \multirow{5}{*}{$\begin{array}{l}\text { b. Follow-up of patients or episodes of care } \\
\text { c. Incomplete outcome data addressed } \\
\text { a. Protection against detection bias: } \\
\text { Intervention unlikely to affect data collection } \\
\text { b. Protection against information bias } \\
\text { c. Data collection appropriate to address } \\
\text { research aims }\end{array}$} & $\mathrm{Y}$ & $\mathrm{N}$ & $\mathrm{N}$ & $\mathrm{N}$ & $\mathrm{N}$ & $\mathrm{N}$ & $\mathrm{N}$ \\
\hline & & & $\mathrm{Y}$ & $\mathrm{Y}$ & $\mathrm{Y}$ & $\mathrm{Y}$ & $\mathrm{Y}$ & YY & $\mathrm{Y}$ \\
\hline & & & $\mathrm{Y}$ & $\mathrm{Y}$ & $\mathrm{Y}$ & $\mathrm{Y}$ & $\mathrm{Y}$ & $\mathrm{N}$ & $\mathrm{N}$ \\
\hline & & & $\mathrm{N}$ & $\mathrm{N}$ & $\mathrm{N}$ & $\mathrm{N}$ & $\mathrm{N}$ & Y & $\mathrm{N}$ \\
\hline & & & $\mathrm{N}$ & $\mathrm{N}$ & $\mathrm{N}$ & $\mathrm{N}$ & $\mathrm{N}$ & $\mathrm{N}$ & $\mathrm{Y}$ \\
\hline \multirow{4}{*}{6} & \multirow{4}{*}{ Analytical rigour } & \multirow{4}{*}{$\begin{array}{l}\text { d. Attempts to mitigate effects of no control } \\
\text { a. Sufficient data points to enable reliable } \\
\text { statistical inference } \\
\text { b. Shaping of intervention effect specified } \\
\text { c. Analysis sufficiently rigorous/free from } \\
\text { bias }\end{array}$} & $\mathrm{N}$ & $\mathrm{N}$ & $\mathrm{N}$ & $Y Y$ & YY & $\mathrm{N}$ & $\mathrm{N}$ \\
\hline & & & $\mathrm{N}$ & $\mathrm{N}$ & $Y Y$ & $\mathrm{~N}$ & $\mathrm{~N}$ & $\mathrm{~N}$ & $\mathrm{~N}$ \\
\hline & & & $\mathrm{N}$ & $\mathrm{N}$ & $\mathrm{Y}$ & $\mathrm{N}$ & $\mathrm{N}$ & $\mathrm{N}$ & $\mathrm{N}$ \\
\hline & & & Y & $\mathrm{Y}$ & $\mathrm{Y}$ & $\mathrm{Y}$ & $\mathrm{Y}$ & $\mathrm{Y}$ & $\mathrm{Y}$ \\
\hline \multirow[t]{5}{*}{7} & $\begin{array}{l}\text { Managing bias in } \\
\text { reporting/ethical } \\
\text { considerations }\end{array}$ & a. Free of selective outcome reporting & $\mathrm{Y}$ & $\mathrm{Y}$ & $\mathrm{Y}$ & Y & Y & $\mathrm{Y}$ & $\mathrm{Y}$ \\
\hline & & b. Limitations addressed & $\mathrm{Y}$ & Y & $\mathrm{Y}$ & Y & $\mathrm{Y}$ & $\mathrm{Y}$ & $\mathrm{Y}$ \\
\hline & & c. Conclusions clear and justified & $\mathrm{Y}$ & Y & Y & Y & $\mathrm{Y}$ & $\mathrm{Y}$ & $\mathrm{Y}$ \\
\hline & & d. Free of other bias & $\mathrm{Y}$ & $\mathrm{Y}$ & $\mathrm{Y}$ & $\mathrm{Y}$ & $\mathrm{Y}$ & $\mathrm{Y}$ & $\mathrm{Y}$ \\
\hline & & e. Ethics issues addressed & $\mathrm{Y}$ & $\mathrm{Y}$ & $\mathrm{Y}$ & $\mathrm{Y}$ & $\mathrm{Y}$ & $\mathrm{Y}$ & $\mathrm{Y}$ \\
\hline
\end{tabular}

${ }^{*}$ Quality criteria applicability to study designs: $\mathrm{Y}=$ criteria to be included in quality assessment for study design; $\mathrm{YY}=$ mandatory criteria to be met for quality assessment; $\mathrm{N}=$ criteria not to be applied in quality assessment for study design. ${ }^{* *}$ Study designs: RCT $=$ randomised controlled trial; CBA = controlled before-after; CITS = controlled interrupted time series; CS = cohort study; NCITS = noncontrolled interrupted time series; NCBA = noncontrolled before-after; $\mathrm{QUAL}=$ qualitative.

\section{Appendix C}

Table A3. ICROMS Decision Matrix-Mandatory Criteria and Minimum Score of Study Type for Inclusion in Review.

\begin{tabular}{ccc}
\hline Study Design & Mandatory Criteria & Minimum Score ${ }^{* *}$ \\
\hline RCT, cRCT & $1 \mathrm{a}, 2 \mathrm{a}, 2 \mathrm{~b}, 3 \mathrm{a}$ & 22 \\
\hline CBA & $1 \mathrm{a}, 2 \mathrm{~d}, 3 \mathrm{~b}, 3 \mathrm{c}$ & 18 \\
\hline CITS & $1 \mathrm{a}, 3 \mathrm{~d}, 6 \mathrm{a}$ & 18 \\
\hline NCITS & $1 \mathrm{a}, 1 \mathrm{~b}, 2 \mathrm{c}, 5 \mathrm{~d}$ & 22 \\
\hline NCBA & $1 \mathrm{a}, 1 \mathrm{~b}, 2 \mathrm{c}, 5 \mathrm{~d}$ & 22 \\
\hline Cohort & $1 \mathrm{a}, 2 \mathrm{e}, 3 \mathrm{~g}, 4 \mathrm{c}$ & 18 \\
\hline Qualitative & $1 \mathrm{a}, 1 \mathrm{e}, 2 \mathrm{f}$ & 16
\end{tabular}

Studies must meet mandatory criteria and a minimum score to be included in review. ${ }^{*}$ Study Designs: RCT $=$ randomised controlled trial; $\mathrm{CBA}=$ controlled before-after; $\mathrm{CITS}=$ controlled interrupted time series; $\mathrm{cRCT}=$ clusterrandomized controlled trial; NCITS = noncontrolled interrupted time series; NCBA = noncontrolled before-after ** Scores applicable to each criteria: Yes (criterion met) $=2$ points; Unclear (unclear whether or not the criterion is met) $=1$ point; No (criterion not met) $=0$ points.

Appendices B and C adapted from Zingg et al., Innovative tools for quality assessment: integrated quality criteria for review of multiple study designs (ICROMS). Public Health 2016, 133, 19-37. 


\section{Appendix D}

Table A4. Score Attributed to Included Articles. Paediatric Antimicrobial Stewardship for Respiratory Infections in the Emergency Setting: A Systematic Review.

\begin{tabular}{cccc}
\hline Study & Study Design & Minimum Score Required & Study Score \\
\hline Ambroggio et al. & Cohort & 18 & 28 \\
\hline Forrest et al. & Cohort & 18 & 24 \\
\hline Huang et al. & NCBA & 22 & 30 \\
\hline May et al. & RCT & 22 & 35 \\
\hline McDaniel et al. & NCBA & 22 & 34 \\
\hline Ouldali et al. & CITS & 18 & 39 \\
\hline Pernica et al. & RCT & 22 & 33 \\
\hline Rutman et al. & Cohort & 18 & 32 \\
\hline Shishido et al. & NCBA & 22 & 36 \\
\hline Van de Maat et al. & RCT & 22 & 36 \\
\hline Weddle et al. & NCBA & 22 & 26 \\
\hline
\end{tabular}

\section{References}

1. Davey, P.; Marwick, C.A.; Scott, C.L.; Charani, E.; McNeil, K.; Brown, E.; Gould, I.M.; Ramsay, C.R.; Michie, S. Interventions to improve antibiotic prescribing practices for hospital inpatients. Cochrane Database Syst. Rev. 2017, 2, CD003543. [CrossRef]

2. DeNegre, A.A.; Ndeffo Mbah, M.L.; Myers, K.; Fefferman, N.H. Emergence of antibiotic resistance in immunocompromised host populations: A case study of emerging antibiotic resistant tuberculosis in AIDS patients. PLoS ONE 2019, 14, e0212969. [CrossRef] [PubMed]

3. Davies, J.; Davies, D. Origins and evolution of antibiotic resistance. Microbiol. Mol. Biol. Rev. 2010, 74, 417-433. [CrossRef] [PubMed]

4. Shenoy, E.S.; Paras, M.L.; Noubary, F.; Walensky, R.P.; Hooper, D.C. Natural history of colonization with methicillin-resistant Staphylococcus aureus (MRSA) and vancomycin-resistant Enterococcus (VRE): A systematic review. BMC Infect. Dis. 2014, 14, 177. [CrossRef]

5. $\quad$ Peters, L.; Olson, L.; Khu, D.T.K.; Linnros, S.; Le, N.K.; Hanberger, H.; Hoang, N.T.B.; Tran, D.M.; Larsson, M. Multiple antibiotic resistance as a risk factor for mortality and prolonged hospital stay: A cohort study among neonatal intensive care patients with hospital-acquired infections caused by gram-negative bacteria in Vietnam. PLoS ONE 2019, 14, e0215666. [CrossRef] [PubMed]

6. Rebelo, M.; Pereira, B.; Lima, J.; Decq-Mota, J.; Vieira, J.D.; Costa, J.N. Predictors of in-hospital mortality in elderly patients with bacteraemia admitted to an Internal Medicine ward. Int. Arch. Med. 2011, 4, 33. [CrossRef]

7. Medernach, R.L.; Logan, L.K. The Growing Threat of Antibiotic Resistance in Children. Infect. Dis Clin. N. Am. 2018, 32, 1-17. [CrossRef]

8. Agiro, A.; Gautam, S.; Wall, E.; Hackell, J.; Helm, M.; Barron, J.; Zaoutis, T.; Fleming-Dutra, K.E.; Hicks, L.A.; Rosenberg, A. Variation in Outpatient Antibiotic Dispensing for Respiratory Infections in Children by Clinician Specialty and Treatment Setting. Pediatric Infect. Dis. J. 2018, 37, 1248-1254. [CrossRef]

9. Gulliford, M.C.; Juszczyk, D.; Prevost, A.T.; Soames, J.; McDermott, L.; Sultana, K.; Wright, M.; Fox, R.; Hay, A.D.; Little, P.; et al. Electronically delivered interventions to reduce antibiotic prescribing for respiratory infections in primary care: Cluster RCT using electronic health records and cohort study. Health Technol. Assess 2019, 23, 1-70. [CrossRef]

10. Martinez-Gonzalez, N.A.; Keizer, E.; Plate, A.; Coenen, S.; Valeri, F.; Verbakel, J.Y.J.; Rosemann, T.; Neuner-Jehle, S.; Senn, O. Point-of-care c-reactive protein testing to reduce antibiotic prescribing for respiratory tract infections in primary care: Systematic review and meta-analysis of randomised controlled trials. Antibiotics 2020, 9, 610. [CrossRef]

11. Schuetz, P.; Wirz, Y.; Sager, R.; Christ-Crain, M.; Stolz, D.; Tamm, M.; Bouadma, L.; Luyt, C.E.; Wolff, M.; Chastre, J.; et al. Procalcitonin to initiate or discontinue antibiotics in acute respiratory tract infections. Cochrane Database Syst. Rev. 2017, 8, 1297-1371. [CrossRef] [PubMed]

12. Dona, D.; Barbieri, E.; Daverio, M.; Lundin, R.; Giaquinto, C.; Zaoutis, T.; Sharland, M. Implementation and impact of pediatric antimicrobial stewardship programs: A systematic scoping review. Antimicrob. Resist Infect. Control 2020, 9, 3. [CrossRef] [PubMed]

13. Ouldali, N.; Bellettre, X.; Milcent, K.; Guedj, R.; De Pontual, L.; Cojocaru, B.; Soussan-Banini, V.; Craiu, I.; Skurnik, D.; Gajdos, V.; et al. Impact of Implementing National Guidelines on Antibiotic Prescriptions for Acute Respiratory Tract Infections in Pediatric Emergency Departments: An Interrupted Time Series Analysis. Clin. Infect. Dis. 2017, 65, 1469-1476. [CrossRef] [PubMed] 
14. Launay, E.; Le Guen, C.G. Antibiotic prescription in paediatric emergency departments: Fear and reason. Lancet Infect. Dis. 2019, 19, 341-342. [CrossRef]

15. Angoulvant, F.; Pereira, M.; Perreaux, F.; Soussan, V.; Pham, L.L.; Trieu, T.V.; Cojocaru, B.; Guedj, R.; Cohen, R.; Alberti, C.; et al. Impact of unlabeled French antibiotic guidelines on antibiotic prescriptions for acute respiratory tract infections in 7 Pediatric Emergency Departments, 2009-2012. Pediatr. Infect. Dis. J. 2014, 33, 330-333. [CrossRef]

16. van de Maat, J.; van de Voort, E.; Mintegi, S.; Gervaix, A.; Nieboer, D.; Moll, H.; Oostenbrink, R.; Research in European Pediatric Emergency Medicine Study Group. Antibiotic prescription for febrile children in European emergency departments: A cross-sectional, observational study. Lancet Infect. Dis. 2019, 19, 382-391. [CrossRef]

17. Aoybamroong, N.; Kantamalee, W.; Thadanipon, K.; Techasaensiri, C.; Malathum, K.; Apiwattanakul, N. Impact of an Antibiotic Stewardship Program on Antibiotic Prescription for Acute Respiratory Tract Infections in Children: A Prospective Before-After Study. Clin. Pediatr. 2019, 58, 1166-1174. [CrossRef]

18. Giubilini, A. Antimicrobial resistance and antimicrobial stewardship programmes: Benefiting the patient or the population? J. Med. Ethics 2017, 43, 653-654. [CrossRef]

19. Masterton, R.G. Antibiotic de-escalation. Crit. Care Clin. 2011, 27, 149-162. [CrossRef] [PubMed]

20. Owens, R.C., Jr. Antimicrobial stewardship: Concepts and strategies in the 21st century. Diagn. Microbiol. Infect. Dis. 2008, 61, 110-128. [CrossRef]

21. Rajar, P.; Saugstad, O.D.; Berild, D.; Dutta, A.; Greisen, G.; Lausten-Thomsen, U.; Mande, S.S.; Nangia, S.; Petersen, F.C.; Dahle, U.R.; et al. Antibiotic Stewardship in Premature Infants: A Systematic Review. Neonatology 2020, 117, 673-686. [CrossRef] [PubMed]

22. Araujo da Silva, A.R.; Marques, A.; Di Biase, C.; Faitanin, M.; Murni, I.; Dramowski, A.; Hubner, J.; Zingg, W. Effectiveness of antimicrobial stewardship programmes in neonatology: A systematic review. Arch. Dis. Child. 2020, 105, 563-568. [CrossRef] [PubMed]

23. Zingg, W.; Castro-Sanchez, E.; Secci, F.V.; Edwards, R.; Drumright, L.N.; Sevdalis, N.; Holmes, A.H. Innovative tools for quality assessment: Integrated quality criteria for review of multiple study designs (ICROMS). Public Health 2016, 133, 19-37. [CrossRef]

24. Ambroggio, L.; Thomson, J.; Kurowski, E.M.; Courter, J.; Statile, A.; Graham, C.; Sheehan, B.; Iyer, S.; Shah, S.S.; White, C.M. Quality improvement methods increase appropriate antibiotic prescribing for childhood pneumonia. Pediatrics 2013, 131, e1623-e1631. [CrossRef] [PubMed]

25. Pernica, J.M.; Harman, S.; Kam, A.J.; Carciumaru, R.; Vanniyasingam, T.; Crawford, T.; Dalgleish, D.; Khan, S.; Slinger, R.S.; Fulford, M.; et al. Short-Course Antimicrobial Therapy for Pediatric Community-Acquired Pneumonia: The SAFER Randomized Clinical Trial. JAMA Pediatrics 2021, 175, 475-482. [CrossRef]

26. Shishido, A.; Otake, S.; Kimura, M.; Tsuzuki, S.; Fukuda, A.; Ishida, A.; Kasai, M.; Kusama, Y. Effects of a nudge-based antimicrobial stewardship program in a pediatric primary emergency medical center. Eur. J. Pediatrics 2021, 180, $1933-1940$. [CrossRef]

27. May, L.; Tatro, G.; Poltavskiy, E.; Mooso, B.; Hon, S.; Bang, H.; Polage, C. Rapid multiplex testing for upper respiratory pathogens in the emergency department: A randomized controlled trial. Open Forum Infect. Dis. 2019, 6, ofz481. [CrossRef]

28. van de Maat, J.S.; Peeters, D.; Nieboer, D.; van Wermeskerken, A.M.; Smit, F.J.; Noordzij, J.G.; Tramper-Stranders, G.; Driessen, G.J.A.; Obihara, C.C.; Punt, J.; et al. Evaluation of a clinical decision rule to guide antibiotic prescription in children with suspected lower respiratory tract infection in The Netherlands: A stepped-wedge cluster randomised trial. PLoS Med. 2020, 17, e1003034. [CrossRef]

29. Yadav, K.; Meeker, D.; Mistry, R.D.; Doctor, J.N.; Fleming-Dutra, K.E.; Fleischman, R.J.; Gaona, S.D.; Stahmer, A.; May, L. A Multifaceted Intervention Improves Prescribing for Acute Respiratory Infection for Adults and Children in Emergency Department and Urgent Care Settings. Acad. Emerg. Med. 2019, 26, 719-731. [CrossRef]

30. Forrest, C.L.; Verzone, A. Antibiotic stewardship: Improving patient-centered right care in urgent care using a shared decision aid and 5 Ds tool. J. Am. Assoc. Nurse Practitioners 2020, 33038113. [CrossRef]

31. Rutman, L.; Wright, D.R.; O'Callaghan, J.; Spencer, S.; Lion, K.C.; Kronman, M.P.; Zhou, C.; Mangione-Smith, R. A Comprehensive Approach to Pediatric Pneumonia: Relationship between Standardization, Antimicrobial Stewardship, Clinical Testing, and Cost. J. Healthc. Qual. 2017, 39, e59-e69. [CrossRef]

32. Huang, Y.C.; Lin, C.F.; Ting, P.J.; Tang, T.H.; Huang, F.L.; Chao, H.J.; Wang, C.L.; Chen, P.Y. Respiratory pathogens-Some altered antibiotic susceptibility after implementation of pneumococcus vaccine and antibiotic control strategies. J. Microbiol. Immunol. Infect. 2020, 53, 682-689. [CrossRef]

33. McDaniel, C.E.; Haaland, W.; Parlaman, J.; Zhou, C.; Desai, A.D. A Multisite Intervention for Pediatric Community-acquired Pneumonia in Community Settings. Acad. Emerg. Med. 2018, 25, 870-879. [CrossRef] [PubMed]

34. Weddle, G.; Goldman, J.; Myers, A.; Newland, J. Impact of an Educational Intervention to Improve Antibiotic Prescribing for Nurse Practitioners in a Pediatric Urgent Care Center. J. Pediatric Health Care Off. Publ. Natl. Assoc. Pediatric Nurse Assoc. Pract. 2017, 31, 184-188. [CrossRef] [PubMed]

35. Zhu, C.; Sidiki, S.; Grider, B.; Fink, B.; Hubbard, N.; Mukundan, D. A Study of the Use and Outcomes from Respiratory Viral Testing at a Mid-Sized Children's Hospital. Clin. Pediatrics 2019, 58, 185-190. [CrossRef]

36. Pulia, M.; Redwood, R.; May, L. Antimicrobial Stewardship in the Emergency Department. Emerg. Med. Clin. North Am. 2018, 36, 853-872. [CrossRef] 
37. Xu, Y.L.; Hu, L.M.; Xie, Z.Z.; Dong, Y.W.; Dong, L. Impact of antimicrobial stewardship program on antimicrobial usage and detection rate of multidrug-resistant gram-negative bacteria. Zhonghua Er Ke Za Zhi = Chin. J. Pediatrics 2019, 57, 553-558. (In Chinese)

38. Savoldi, A.; Foschi, F.; Kreth, F.; Gladstone, B.P.; Carrara, E.; Eisenbeis, S.; Buhl, M.; Marasca, G.; Bovo, C.; Malek, N.P.; et al. Impact of implementing a non-restrictive antibiotic stewardship program in an emergency department: A four-year quasi-experimental prospective study. Sci. Rep. 2020, 10, 8194. [CrossRef] [PubMed]

39. May, L.; Nguyen, M.H.; Trajano, R.; Tancredi, D.; Aliyev, E.R.; Mooso, B.; Anderson, C.; Ondak, S.; Yang, N.; Cohen, S.; et al. A multifaceted intervention improves antibiotic stewardship for skin and soft tissues infections. Am. J. Emerg. Med. 2021, 46, 374-381. [CrossRef]

40. Calo, F.; Onorato, L.; Macera, M.; Di Caprio, G.; Monari, C.; Russo, A.; Galdieri, A.; Giordano, A.; Cuccaro, P.; Coppola, N. Impact of an Education-Based Antimicrobial Stewardship Program on the Appropriateness of Antibiotic Prescribing: Results of a Multicenter Observational Study. Antibiotics 2021, 10, 314. [CrossRef]

41. Penalva, G.; Fernandez-Urrusuno, R.; Turmo, J.M.; Hernandez-Soto, R.; Pajares, I.; Carrion, L.; Vazquez-Cruz, I.; Botello, B.; Garcia-Robredo, B.; Camara-Mestres, M.; et al. Long-term impact of an educational antimicrobial stewardship programme in primary care on infections caused by extended-spectrum beta-lactamase-producing Escherichia coli in the community: An interrupted time-series analysis. Lancet Infect. Dis. 2020, 20, 199-207. [CrossRef]

42. Kjaersgaard, M.; Leth, R.A.; Udupi, A.; Ank, N. Antibiotic stewardship based on education: Minor impact on knowledge, perception and attitude. Infect. Dis. 2019, 51, 753-763. [CrossRef] [PubMed]

43. Fowler, S.; Weber, A.; Cooper, B.S.; Phimister, A.; Price, K.; Carter, Y.; Kibbler, C.C.; Simpson, A.J.H.; Stone, S.P. Successful use of feedback to improve antibiotic prescribing and reduce Clostridium difficile infection: A controlled interrupted time series. J. Antimicrob. Chemother. 2007, 59, 990-995. [CrossRef]

44. Baysari, M.T.; Egan, K.O.B.; Li, L.; Richardson, K.; Sandaradura, I.; Westbrook, J.I.; Day, R.O. Audit and feedback of antibiotic use: Utilising electronic prescription data. Appl. Clin. Inform. 2013, 4, 583-595. [PubMed]

45. Dodd, M.; Adolphe, A.; Parada, A.; Brett, M.; Culbreath, K.; Mercier, R.C. Clinical Impact of a Rapid Streptococcal Antigen Test on Antibiotic Use in Adult Patients. Diagn. Microbiol. Infect. Dis. 2018, 91, 339-344. [CrossRef] [PubMed]

46. Rogan, D.T.; Kochar, M.S.; Yang, S.; Quinn, J.V. Impact of Rapid Molecular Respiratory Virus Testing on Real-Time Decision Making in a Pediatric Emergency Department. J. Mol. Diagn. 2017, 19, 460-467. [CrossRef]

47. Brotherton, A.L. Metrics of Antimicrobial Stewardship Programs. Med. Clin. North Am. 2018, 102, 965-976. [CrossRef]

48. Acworth, J.; Babl, F.; Borland, M.; Ngo, P.; Krieser, D.; Schutz, J.; Pitt, R.; Cotterell, E.; Jamison, S.; Neutze, J.; et al. Patterns of presentation to the Australian and New Zealand Paediatric Emergency Research Network. Emerg. Med. Australas 2009, 21, 59-66. [CrossRef] 